\title{
Genetic diversity and breeding system variation in Daphnia pulicaria from North American lakes
}

\author{
MARTIN ČERNÝ* \& PAUL D. N. HEBERT† \\ Department of Hydrobiology, Charles University, Prague, CS-128 44, Czech Republic; tDepartment of Zoology, \\ University of Guelph, Guelph, Ontario, Canada N1G 2W1
}

\begin{abstract}
Comparative distributional studies of closely related taxa suggest that sexuals dominate in stable habitats, while asexuals are most abundant in disturbed environments. For freshwater zooplankton, temporary ponds represent unstable systems in which populations must be re-established from diapausing eggs, while lakes are relatively stable habitats permitting populations to persist all year round. This study involves the comparison of breeding systems in populations of the zooplankter Daphnia pulicaria from lake and pond habitats. In common with other members of the genus, some populations of this species have made the transition from cyclic parthenogenesis, in which sexual reproduction is a regular part of the life cycle, to obligate parthenogenesis. Prior work has shown that populations of $D$. pulicaria from ponds in central Canada largely reproduce by obligate parthenogenesis. However, this study shows that cyclic parthenogenesis is the dominant mode of reproduction in lake populations of $D$. pulicaria in two regions of the USA. Obligately asexual lake populations were more frequent in the western than central states, a pattern which may be due to regional variation in the extent of interspecific gene flow from the closely related species $D$. pulex.
\end{abstract}

Keywords: allozymes, breeding systems, Daphnia, parthenogenesis, zooplankton.

\section{Introduction}

Cyclic parthenogenesis is both the dominant and ancestral mode of reproduction in cladoceran crustaceans, but some species have made the transition to obligate asexuality (Hebert, 1987). In such taxa both subitaneous and resting eggs are produced asexually, while in cyclically parthenogenetic species the resting eggs are produced sexually. The most detailed analysis of factors promoting this breeding system transition has involved the analysis of Daphnia pulex Linne emend. Levdig and its closest relative D. pulicaria Forbes. These studies (Hebert et al., 1989a; Lynch et al., 1989; Weider \& Hebert, 1987; Weider et al., 1987; Hebert et al., 1993) have demonstrated that both species show regional and local variation in their breeding systems.

This past work has focused on populations from shallow ponds, as breeding systems can be diagnosed with confidence in these settings, because populations are regularly reinitiated from resting eggs. Obligately asexual populations show low genotypic diversity and

\footnotetext{
*Correspondence.
}

gross disturbances from Hardy Weinberg (H. W. ) equilibrium, while populations reproducing by cyclic parthenogenesis show high genotypic diversity and the congruence of genotypic frequencies to $\mathrm{H}$. W. expectations. Prior studies have shown that short bouts of asexual reproduction following re-establishment from resting eggs do not have substantial impacts on the genotypic composition of cyclically parthenogenetic populations (Hebert, 1987), ensuring that breeding systems can be reliably diagnosed from the analysis of allozyme markers.

Much less work has been directed towards the analysis of breeding system diversity in lake daphniids because of the potential for interpretational uncertainty. These difficulties arise because work on pond daphniids has shown that when sexual recruitment is rare and the opportunity exists for sustained reproduction via subitaneous eggs, then cyclically parthenogenetic populations can develop genetic characteristics which mimic those of obligate asexuals (Hebert, 1978). It was presumed that similar $\mathrm{H}$. W. disturbances and low genotypic diversity would be the rule in cyclically parthenogenetic populations from lake environments, where there is no recurrent need to re-establish 
populations from resting eggs. The genetic data now available challenge this conclusion and show that genotypic frequencies are often in $\mathrm{H}$. W. equilibrium (Mort \& Wolf, 1985; 1986). Obviously sexual recruitment is more pervasive in lake populations of Daphnia than was initially supposed. However, H. W. disturbances have been detected in enough populations known to reproduce by cyclic parthenogenesis (Hebert et al., 1989b; Jacobs, 1990) to make it clear that H. W. deviations can reflect either the adoption of obligate asexuality or the suppression of sexual recruits in a cyclic parthenogenetic population. Fortunately, a similar interpretational uncertainty does not apply to the converse situation - when genotypic diversity is high and frequencies approximate $\mathrm{H}$. W. expectations, it can reasonably be concluded that the population under study reproduces via cyclic parthenogenesis.

This study examines patterns of genetic diversity in populations of $D$. pulicaria from lakes in two regions of temperate North America. Prior work has shown that most populations of this species from pond habitats in central Canada are obligate asexuals, while those in far western Canada are cyclic parthenogens (Hebert et al.,
1993). The present study employs allozyme analysis to discover if there is a similar pattern of breeding system variation in lake settings.

\section{Materials and methods}

Populations of $D$. pulicaria were sampled from 55 permanent waterbodies (Table 1) comprising both lakes and reservoirs at sites across Ontario and 11 US states. The type locality (Yellowstone Lake) for the species (Hrbáček, 1957) was included among these sites. These populations were subdivided into a group of 19 populations from six western states and a group of 36 populations from five central states and Ontario. Out of the group of 36 populations, 23 were obtained from lakes in north-eastern Indiana, permitting a particularly detailed analysis of variation in breeding systems at this locality.

Sites were sampled in the spring and early summer of 1990 and 1991, shortly after the recruitment of individuals from resting eggs was likely to reach its peak. Samples were ordinarily collected by towing a plankton net in the deepest part of each lake, but a few

Table 1 List of North American lakes classified by region and state where genetic diversity and breeding system variation in Daphnia pulicaria was investigated

\begin{tabular}{|c|c|c|c|}
\hline Region & State & Code & Population (county) \\
\hline Central & Indiana & $\begin{array}{l}\text { in1 } \\
\text { in2 } \\
\text { in3 } \\
\text { in4 } \\
\text { in5 } \\
\text { in6 } \\
\text { in7 } \\
\text { in8 } \\
\text { in9 } \\
\text { in10 } \\
\text { in11 } \\
\text { in } 12 \\
\text { in13 } \\
\text { in14 } \\
\text { in15 } \\
\text { in16 } \\
\text { in17 } \\
\text { in18 } \\
\text { in19 } \\
\text { in20 } \\
\text { in21 } \\
\text { in22 } \\
\text { in23 } \\
\text { in24 } \\
\text { in25 } \\
\text { in26 }\end{array}$ & $\begin{array}{l}\text { Adams Lake (LaGrange) } \\
\text { Bear Lake (Noble) } \\
\text { Big Lake (Noble) } \\
\text { Blue Lake (Whitley) } \\
\text { Cedar Lake (Whitley) } \\
\text { Crane Lake (Noble) } \\
\text { Crooked Lake (Whitley/Noble) } \\
\text { Eagle Lake (Noble) } \\
\text { Fish Lake (LaGrange) } \\
\text { High Lake (Noble) } \\
\text { Little Cedar Lake (Whitley) } \\
\text { Little Crooked Lake (Whitley/Noble) } \\
\text { Loon Lake 1991 (Noble/Whitley) } \\
\text { Loon Lake 1990 (Noble/Whitley) } \\
\text { Old Lake (Whitley) } \\
\text { Oliver Lake (LaGrange) } \\
\text { Round Lake (Whitley) } \\
\text { Smalley Lake (Noble) } \\
\text { Sylvan Lake (Noble) } \\
\text { Tippecanoe Lake (Kosciusko) } \\
\text { Waubee Lake } 1991 \text { (Kosciusko) } \\
\text { Waubee Lake } 1990 \text { (Kosciusko) } \\
\text { Wawasee Lake } 1991 \text { (Kosciusko) } \\
\text { Wawasee Lake } 1990 \text { (Kosciusko) } \\
\text { Westler Lake (LaGrange) } \\
\text { Winona Lake (Kosciusko) }\end{array}$ \\
\hline
\end{tabular}


Table 1 Continued

\begin{tabular}{|c|c|c|c|}
\hline Region & State & Code & Population (county) \\
\hline Central & Iowa & $\begin{array}{l}\text { io1 } \\
\text { io2 }\end{array}$ & $\begin{array}{l}\text { Storm Lake (Buena Vista) } \\
\text { Lost Island Lake (Palo Alto) }\end{array}$ \\
\hline Central & Michigan & $\begin{array}{l}\mathrm{mi} 1 \\
\mathrm{mi} 2 \\
\mathrm{mi} 3\end{array}$ & $\begin{array}{l}\text { Cedar Lake (Van Buren) } \\
\text { Hemlock Lake (Cass) } \\
\text { Silver Lake at Wolverine (Cheboygan) }\end{array}$ \\
\hline Central & Minnesota & $\begin{array}{l}\mathrm{mn} 1 \\
\mathrm{mn} 2\end{array}$ & $\begin{array}{l}\text { Maple Lake (Itasca) } \\
\text { Swan Lake (Itasca) }\end{array}$ \\
\hline Central & Ontario & $\begin{array}{l}\text { on1 } \\
\text { on2 }\end{array}$ & $\begin{array}{l}\text { Haynes Lake (York) } \\
\text { Lake at Rossport (Thunder Bay) }\end{array}$ \\
\hline Central & Wisconsin & $\begin{array}{l}\text { wi1 } \\
\text { wi2 } \\
\text { wi3 } \\
\text { wi4 } \\
\text { wi5 }\end{array}$ & $\begin{array}{l}\text { Kegonsa Lake (Dane) } \\
\text { Lake Mendota May } 1991 \text { (Dane) } \\
\text { Lake Mendota July } 1991 \text { (Dane) } \\
\text { Lake Monona (Dane) } \\
\text { Lake Waubesa (Dane) }\end{array}$ \\
\hline West & California & $\begin{array}{l}\mathrm{ca} 1 \\
\mathrm{ca} 2 \\
\mathrm{ca} 3\end{array}$ & $\begin{array}{l}\text { Lucerne Lake (Mateo) } \\
\text { Shasta Lake (Shasta) } \\
\text { Whiskeytown Lake (Shasta) }\end{array}$ \\
\hline West & Colorado & $\begin{array}{l}\operatorname{co} 1 \\
\operatorname{co} 2 \\
\operatorname{co} 3 \\
\operatorname{co} 4\end{array}$ & $\begin{array}{l}\text { Cucharas Reservoir (Huefrano) } \\
\text { Granby Lake (Grand) } \\
\text { Lake Meredith (Crowley) } \\
\text { Lake at Pagosa Springs (Archuleta) }\end{array}$ \\
\hline West & Idaho & id1 & Palisades Reservoir (Bonneville) \\
\hline West & Nevada & $\begin{array}{l}\text { ne1 } \\
\text { ne2 } \\
\text { ne3 }\end{array}$ & $\begin{array}{l}\text { Jiggs Reservoir (Elko) } \\
\text { Lahontan Reservoir (Lyon/Churchill) } \\
\text { Washoe Lake (Washoe) }\end{array}$ \\
\hline West & Utah & $\begin{array}{l}\text { ut } 1 \\
\text { ut2 } \\
\text { ut3 } \\
\text { ut4 }\end{array}$ & $\begin{array}{l}\text { Deer Creek Reservoir (Wasatch) } \\
\text { Koosharem Reservoir (Sevier) } \\
\text { Otter Creek Reservior (Piute) } \\
\text { Starvation Lake (Duchesne) }\end{array}$ \\
\hline West & Wyoming & $\begin{array}{l}\text { wy1 } \\
\text { wy2 } \\
\text { wy3 } \\
\text { wy4 }\end{array}$ & $\begin{array}{l}\text { Big Sand Reservoir (Sublette) } \\
\text { Lewis Lake (Yellowstone) } \\
\text { Soda Lake (Sublette) } \\
\text { Yellowstone Lake(Yellowstone) }\end{array}$ \\
\hline
\end{tabular}

lakes were sampled from shore. All samples were sorted in the field and when possible at least 60 individuals of $D$. pulex or $D$. pulicaria were frozen in liquid nitrogen.

Although $D$. pulex and $D$. pulicaria are morphologically distinct, their discrimination is complicated by the occurrence of $F_{1}$ hybrids. However, past studies have revealed fixed allozyme differences which can be used in species diagnosis (Hebert et al., 1989a). In this study all individuals homozygous for the $F$ allele at the $\mathrm{LDH}$ locus were classified as $D$. pulicaria, while individuals homozygous for the $\mathrm{S}$ allele were catagorized as $D$. pulex. Individuals heterozygous at $L D H$ (lactate dehydrogenase) were presumed to be $F_{1}$ hybrids. Populations assigned to $D$. pulicaria ordinarily contained only individuals with a head shape similar to that of D. pulicaria (Brandlová et al., 1972, =D. schoedleri sensu Brooks, 1957). It is possible that some individuals categorized either as hybrids or $D$. pulex represent $D$. pulicaria introgressants, but exclusion of this possibility requires more detailed analysis of the populations containing such individuals. It is worth noting that the mistaken exclusion of true introgressants has no effect on the breeding system diagnosis. By contrast, their retention, if they represent reproductively isolated units, would enhance the incidence of $\mathrm{H}$. W. disturbances and hence exaggerate the incidence of asexual populations. 
To assess the genotypic structure of each population, at least 40 individuals were scored for allozyme variation at both $L D H$ and six additional loci (Aldehydeoxidase, AO; Fumerase, FUM; Glutamateoxaloacetate transferase, GOT; Mannose phosphate isomerase, MPI; Phosphoglucose isomerase, PGI; Phosphoglucomutase $P G M$ ) which are commonly polymorphic in the $D$. pulex complex. Alleles were assigned a letter code $(B=$ slowest, $S=$ slow, $M=$ medium, $F=$ fast and $Q=$ fastest). All electrophoresis was carried out on Titan III cellulose acetate plates employing standard methods (Hebert \& Beaton, 1989). In most cases all 40 individuals were assigned, on the basis of $L D H$ phenotype, to $D$. pulicaria. In other cases sample size was reduced by the presence of $D$. pulex or hybrids. The gene frequency data on $D$. pulicaria were employed as a basis for two analyses. The extent of gene frequency divergence among populations was evaluated using Wright's (1978) hierarchical $F$-statistics approach and calculated using BIOsYs-1 (Swofford \& Selander, 1989). The significance of $F$ values for each hierarchical level was subsequently tested using the $\chi^{2}$ analysis developed by Workman and Niswander (1970). The gene frequency data were subsequently pooled for all populations from each province or state and Nei's (1978) unbiased genetic distances were calculated for each group of populations. The genetic relatedness of these groups of populations was later evaluated using the unweighted pair-group clustering method in BIOsYs-1.

Fifty-two populations of $D$. pulicaria were represented by sufficient individuals $(>15)$ to permit breeding system assignments. The breeding systems of two populations were classified as uncertain because they were monomorphic at each of the six loci. The remaining populations were polymorphic at one or more loci, and three parameters useful in breeding system determination were calculated for each of these populations: the number of multi-locus genotypes identified, the log-transformed probability of the observed genotypic array at each polymorphic locus being in $\mathrm{H}$. W. equilibrium, and the genotypic diversity ratio (GDR: the observed number of multi-locus genotypes in the sample divided by the expected number in a similarly sized sample from a sexual population with the same gene frequencies).

These three parameters were calculated using the methods described in Hebert et al. (1988), and decisions concerning the breeding system were based on rules employed by Hebert et al. (1993): i.e. populations were designated as cyclic parthenogens when the probability that genotypic frequencies were in $\mathrm{H}$. W. equilibrium was greater than 5 per cent and the GDR was at least 0.70 . Populations were assigned as obligate parthenogens when genotypic frequencies deviated significantly $(P<0.05)$ from $\mathrm{H}$. W. equilibrium and when the GDR was lower than 0.70 . Populations lacking significant deviations from $\mathrm{H}$. W. equilibrium but with a low GDR $(<0.70)$ were designated as possessing an uncertain breeding system, as were those significantly deviant from $\mathrm{H}$. W. equilibrium, but with a high GDR $(>0.70)$.

\section{Results}

\section{Taxon distributions}

Based on the analyses of $L D H$ phenotypes, D. pulicaria comprised more than 91 per cent of the 2268 individuals from the 55 habitats. $D$. pulicaria was the sole species at 45 of these sites and dominated at six of the remaining localities (Table 2). In five lakes either $D$. pulex or hybrids co-occurred with $D$. pulicaria, while at the other 5 localities all three taxa co-occurred. At one of the sites (Lake Mendota) there was some evidence for temporal variation in abundances of the taxa. Morphological comparison of individuals assigned to each of three taxa at this site indicated that differences in head shape were small or absent among them.

\section{Gene frequency variation}

Four of the six loci commonly polymorphic in members of the D. pulex complex (Hebert et al., 1993) were invariant in most lake populations of $D$. pulicaria (Table 3). All populations were fixed for the $M$ allele at $F U M$ and all except two populations from Nevada (ne2 and ne 3 ) were monomorphic for the $F$ allele at $A O$. (The data for $F U M$ and $A O$ loci are not shown in Table 3.) The same lack of variation was noted at $G O T$

Table 2 Proportions of Daphnia pulex, hybrids and $D$. pulicaria at 10 localities where two or more taxa were found to co-occur (px, D. pulex; $F_{1}$, hybrids; pul, D. pulicaria)

\begin{tabular}{llllll}
\hline & $n$ & $\mathrm{px}$ & $\mathrm{F}_{1}$ & pul \\
\cline { 1 - 2 } Co, Pagosa Springs & & 40 & 0.00 & 0.57 & 0.42 \\
Io, Lost Island & 40 & 0.85 & 0.03 & 0.13 \\
In, Wawasee 90 & 38 & 0.03 & 0.00 & 0.97 \\
Mn, Maple & 40 & 0.03 & 0.00 & 0.98 \\
Ne, Washoe & 39 & 0.08 & 0.26 & 0.67 \\
On, Haynes & 40 & 0.00 & 0.87 & 0.13 \\
Wi, Kegonsa & 55 & 0.00 & 0.09 & 0.91 \\
Wi, Mendota May & 40 & 0.18 & 0.17 & 0.65 \\
& 40 & 0.03 & 0.45 & 0.53 \\
Wi, Monona & 40 & 0.03 & 0.05 & 0.92 \\
Wi, Waubesa & 39 & 0.59 & 0.03 & 0.38 \\
\hline
\end{tabular}




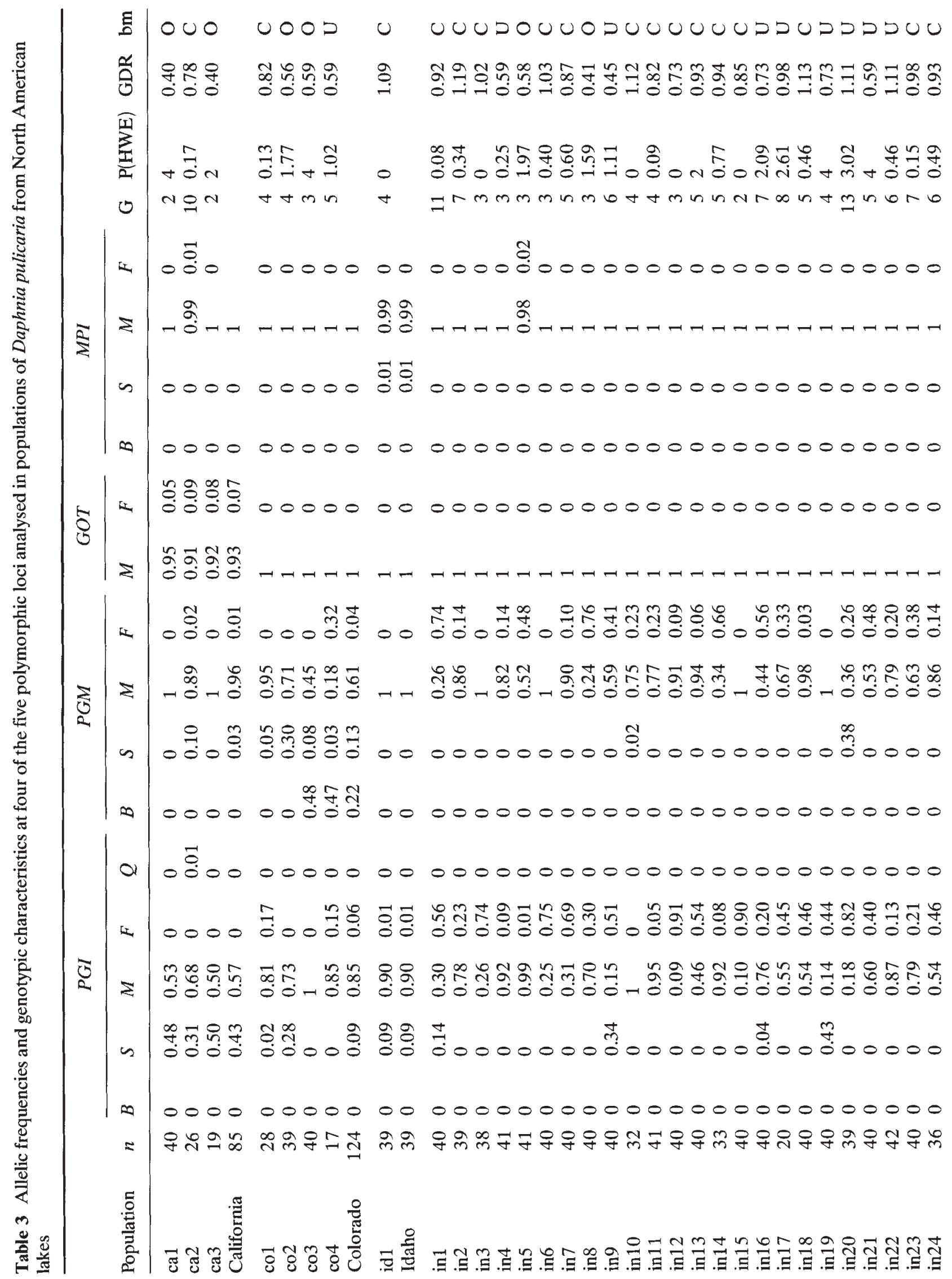




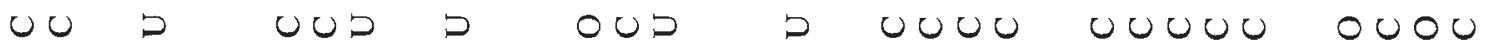

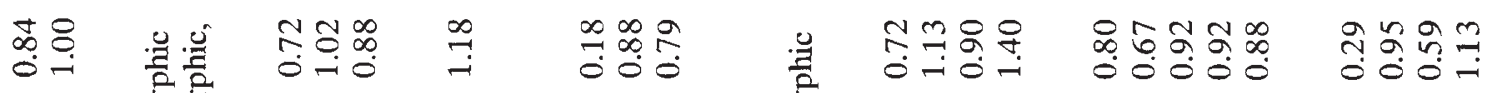

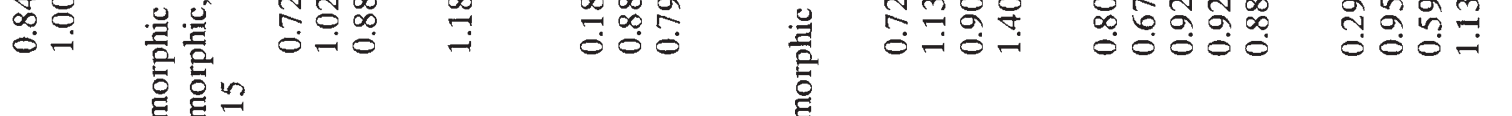

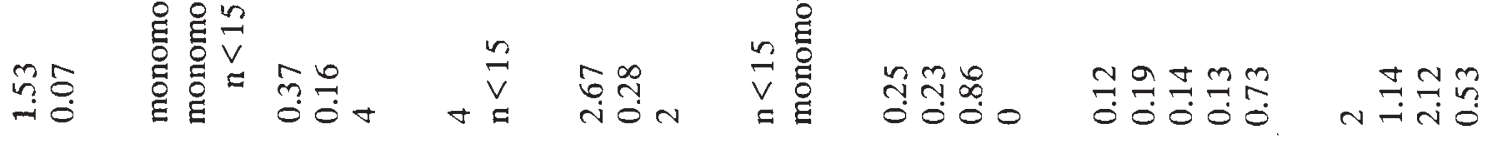

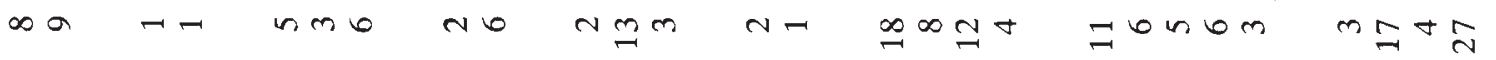

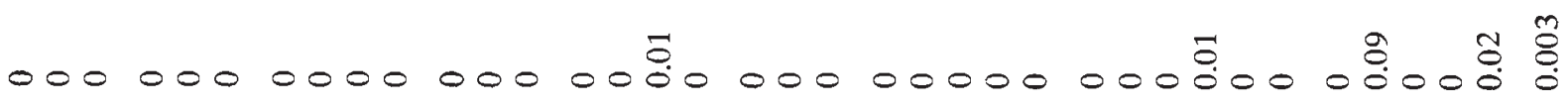

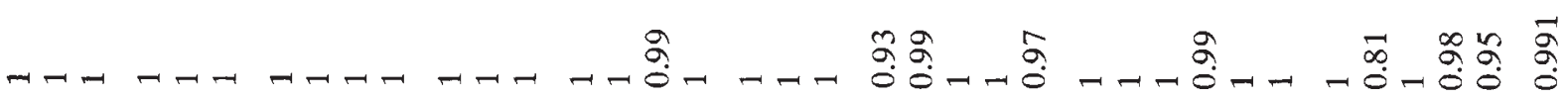
$0000000000000000000000000000000000 \%$ $000000000000000000 \hat{0} \dot{0} 00 \stackrel{m}{0} 00000000000 \hat{0}$

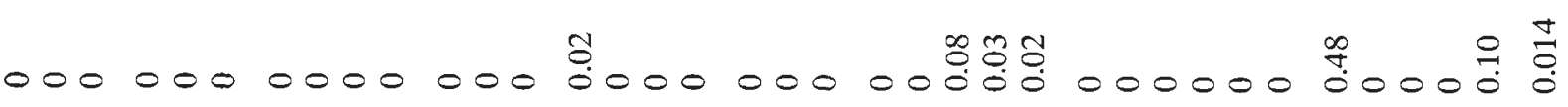

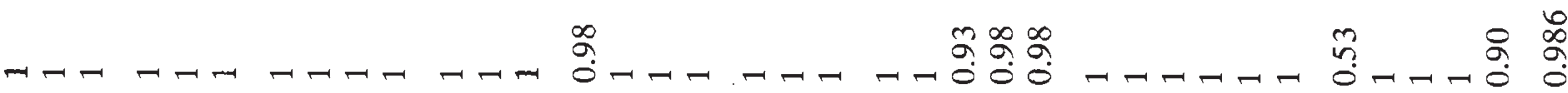

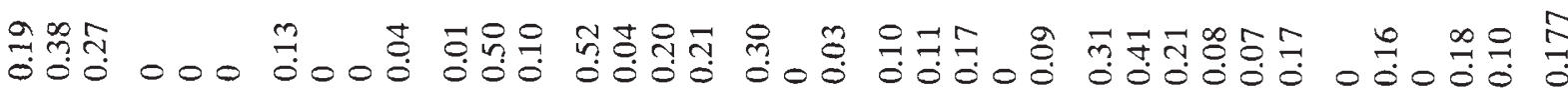

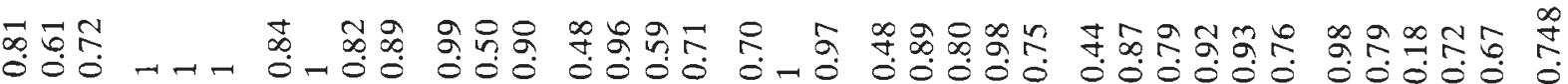

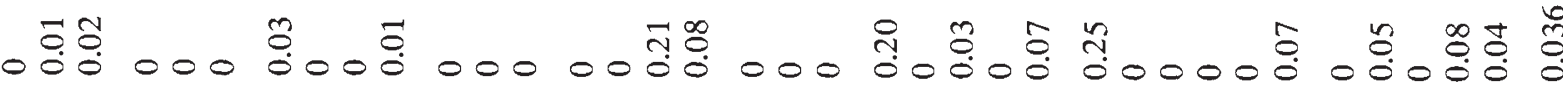

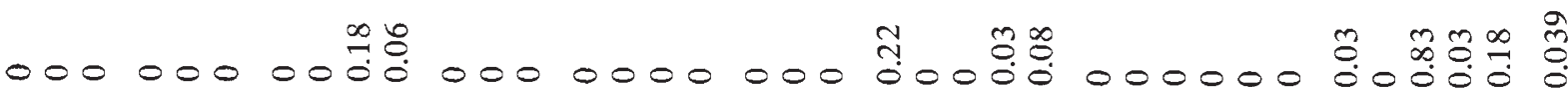
$0000000000000.00000000000000000000000 \%$

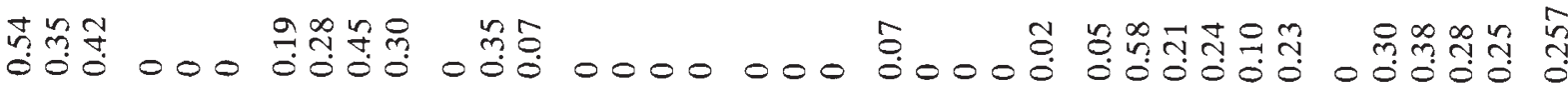

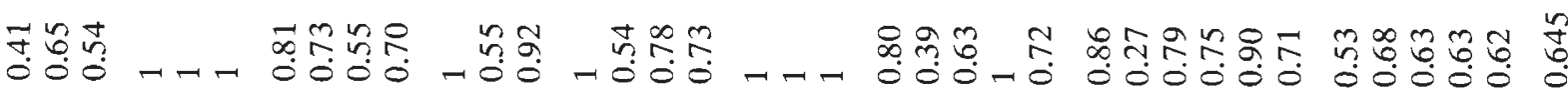

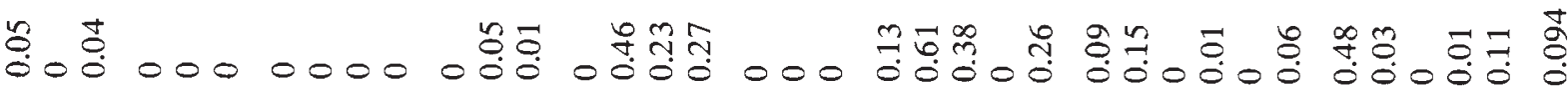
$00000000000 \stackrel{0}{0} 00000000000000000000000$ :

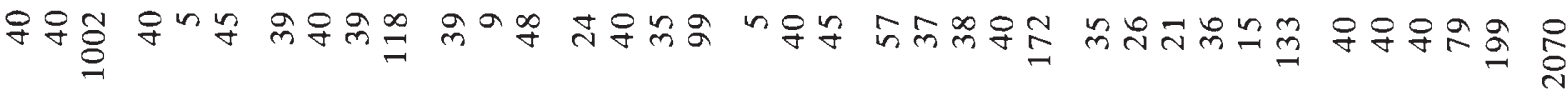

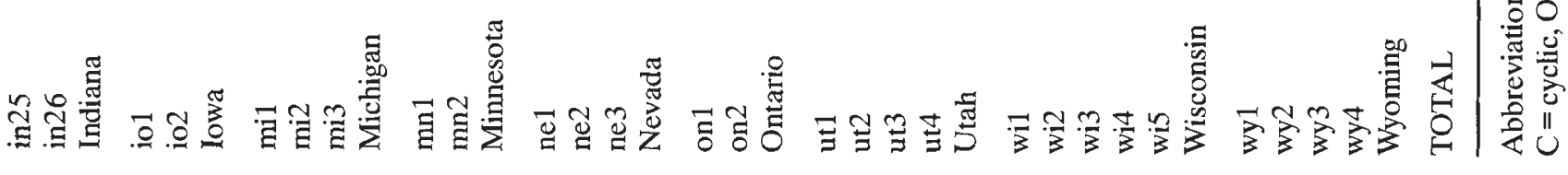


among populations of $D$. pulicaria from eastern North America, but the $F$ allele was present in populations from four of the six western states. The $M$ allele was similarly dominant in all populations at $M P I$, although three additional alleles were detected rarely at some localities.

The $P G M$ and $P G I$ loci were considerably more variable, with four alleles detected at each locus (Table 3). PGI showed evidence of a regional shift in gene frequency, with the slow allele much more common in western than eastern populations (Fig. 1a). Allele frequencies at the $P G M$ locus also showed marked variation among sites, but there was no obvious geographical patterning to this diversity (Fig. 1b).
The hierarchical analyses of the regional gene frequency divergence for the two most polymorphic loci $(P G I, P G M)$ showed that the bulk of variance in gene frequencies existed among the lakes in a single state or province (Table 4). The additional divergence among populations from different states or provinces and between the central and western groups of populations, although significantly different from 0 , was negligible compared to the gene frequency differentation among local populations.

The unweighted pair-group clustering method in BIOSYS-1 showed that genetic distances among populations from the 12 states and provinces were small (Fig. 2). Although there was little evidence of geographical patterning in lake populations of $D$. pulicaria, those

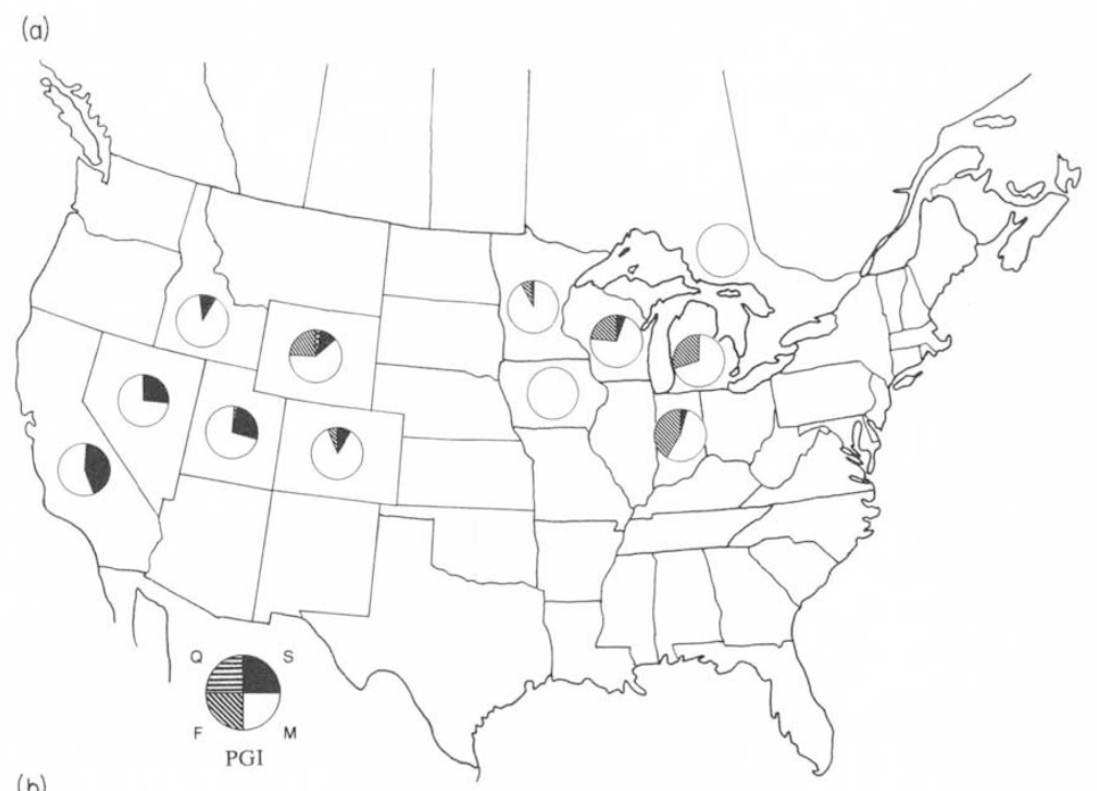

(b)

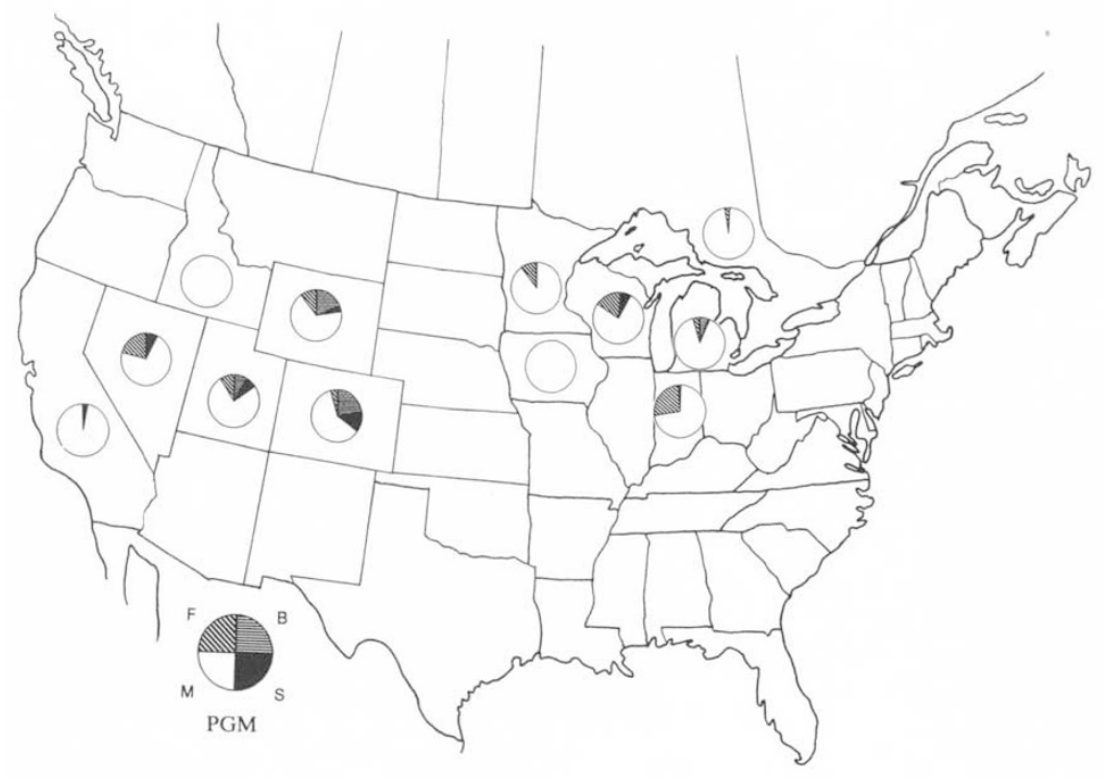

Fig. 1 Geographical patterning of gene frequencies at (a) $P G I$ and (b) $P G M$ loci in Daphnia pulicaria. 
Table 4 Hierarchical analysis of gene frequency diversity in populations of Daphnia pulicaria for two polymorphic loci

\begin{tabular}{lllllllll}
\hline & DS & d.f. & SR & d.f. & RT & d.f. & DT & d.f. \\
\hline$P G I$ & $0.290^{*}$ & 44 & $0.023^{*}$ & 35 & $0.025^{*}$ & 4 & $0.323^{*}$ & 188 \\
$P G M$ & $0.242^{*}$ & 33 & 0 & - & 0 & - & $0.230^{*}$ & 141 \\
Mean & $0.268^{*}$ & 77 & $0.007^{*}$ & 35 & $0.012^{*}$ & 4 & $0.282^{*}$ & 321 \\
\hline
\end{tabular}

*Significantly different from 0 at $P=0.001$.

Abbreviations: DS, differentiation among populations (D) from a single state or province (S); SR, differentiation among states $(\mathrm{S})$ in a region $(\mathrm{R}) ; \mathrm{RT}$, differentiation between regions (R) in total area (T); DT, differentiation among populations (D) in total area (T); d.f., degrees of freedom. Method from Wright, 1978.

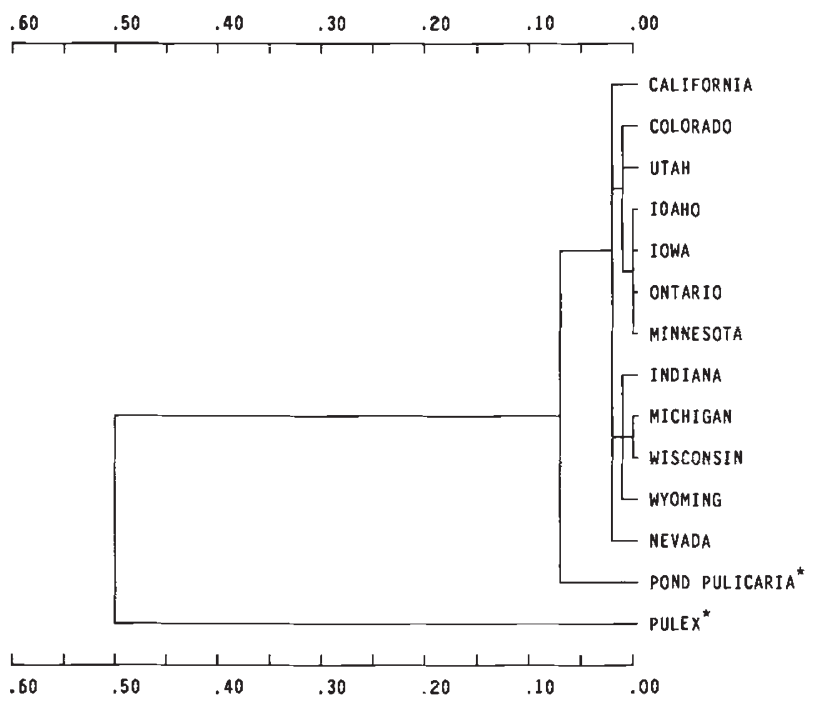

Fig. 2 Unweighted pair-group clustering of genetic distances (Nei, 1978) among lake populations of Daphnia pulicaria from 12 states and provinces in North America, based on frequencies of seven commonly variable loci. *Data on $D$. pulex and pond D. pulicaria from Hebert et al. (1993) were included for comparison.

from pond habitats in western Canada were clearly distinct from the lake populations.

\section{Breeding system diversity}

All three parameters employed in breeding system assignments varied considerably among the populations. Clone richness ranged from 2 to 27 , with the highest diversity evident in the west. For example, 32 per cent of the populations from western localities contained 10 or more clones, while only 9 per cent of eastern populations exceeded this threshold. Geno-

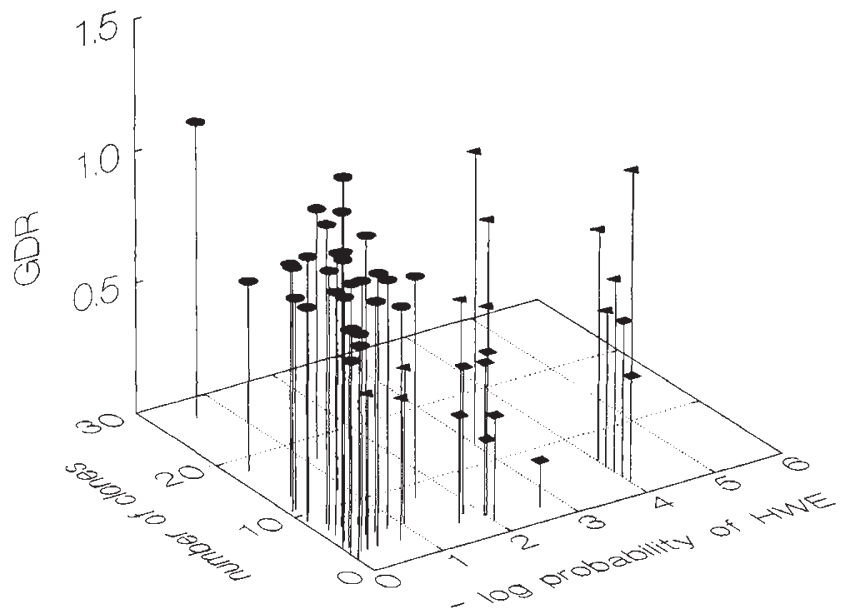

Fig. 3 Genotypic characteristics of Daphnia pulicaria populations from lakes in central and western North America. $\square$, obligate asexual; $\bullet$, cyclic parthenogens; $\mathbf{\Lambda}$, uncertain. Abbreviations: GDR, genotypic diversity ratio; HWE, H. W. equilibrium.

typic frequencies in most populations approximated $\mathrm{H}$. W. equilibrium, but large deviations were detected at a few sites. Finally, GDRs ranged from a low of 0.18 to a high of 1.40 .

The breeding system assignments based on these three parameters suggested that 62 per cent of the populations reproduce by cyclic parthenogenesis, while 17 per cent are obligate asexuals (Fig. 3). Breeding system assignments for the other 21 per cent of the populations were uncertain. Two of the populations included in this 'uncertain' category were completely invariant, making a genetic determination of breeding system impossible. However, the majority of populations in this category were genetically variable, but showed either a lower number of genotypes than expected in a sexual population or significant $\mathrm{H}$. W. deviations.

Three of the Indiana populations were resampled in consecutive years and the Lake Mendota population was sampled in May and July of 1991. Although samples from one of the Indiana lakes (Wawasee) were consistently designated as cyclic parthenogens, populations from the other Indiana lake (Loon) and Lake Mendota were designated as uncertain on one occasion and as cyclically parthenogenetic for the other. Both populations were treated as cyclical parthenogens. The Indiana population at Waubee, which was sampled twice, showed a major shift in genotypic composition, which led to its categorization as a cyclical parthenogen in 1990 and an obligate parthenogen in 1991. Because of this shift, the population was assigned an uncertain breeding mode (Table 3). 


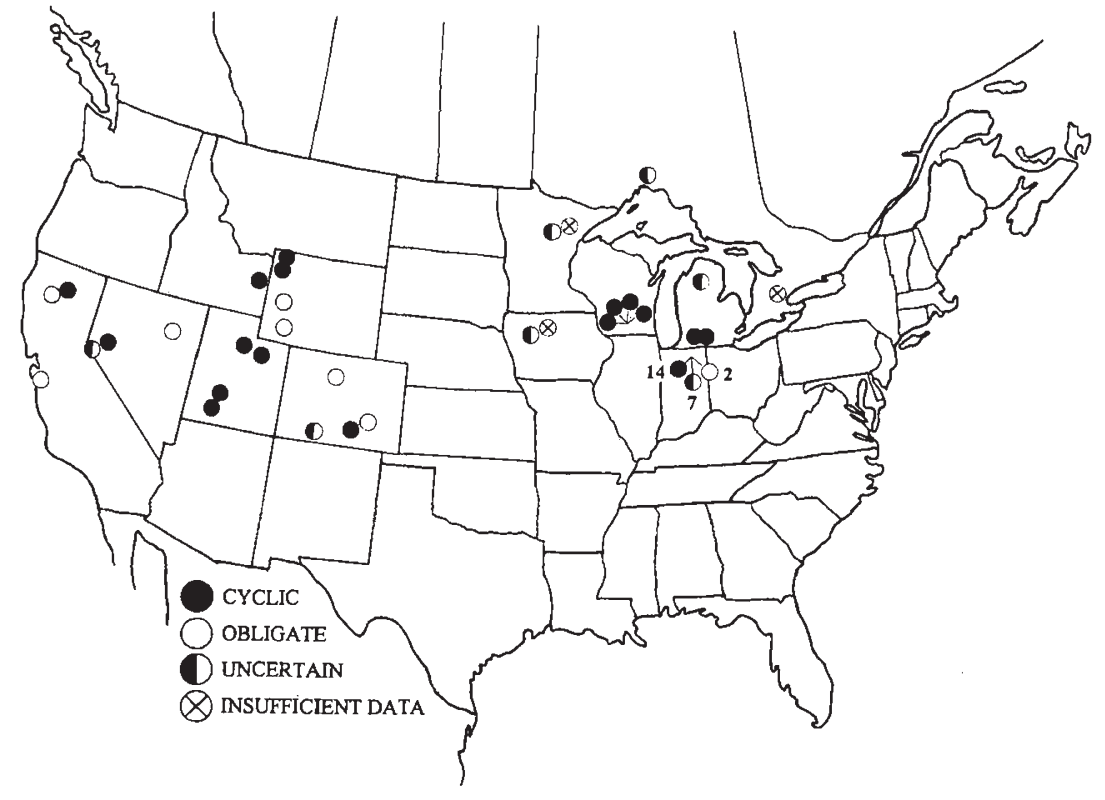

Fig. 4 Breeding system assignments for individual populations of Daphnia pulicaria. The numerals beside each pie in Indiana indicate the number of populations assigned to each category.
There was some evidence of a significant geographical shift in breeding systems $\left(G_{\text {adj }}=5.79\right.$, d.f. $=1$, $P<0.05$ ) since 36 per cent of the populations ( 7 of 19 ) from the western states appeared to reproduce by obligate parthenogenesis compared with only 6 per cent of the central populations ( 2 of 33). The detailed study of lakes in Indiana provided evidence of the local co-occurrence of both breeding systems since although most of the populations were cyclic parthenogens, two lakes in this state appeared to contain obligately asexual populations (Fig. 4).

\section{Discussion}

Studies of breeding system diversity in the $D$. pulex complex have been complicated by difficulties in discriminating between $D$. pulex and $D$. pulicaria. Over the past decade it has become clear that much of this taxonomic confusion arises because of the prevalence of $F_{1}$ hybrids between the two species. Recent work has indicated that diagnostic substitutions at $L D H$ and $P E P$ can be employed in taxon recognition (Hebert et al., 1989a; 1993). The present study is the first to use a genetic criterion in the analysis of lake-dwelling members of the complex. This analysis indicated that D. pulicaria dominates lake habitats across North America, but also suggested the presence of $D$. pulex and $F_{1}$ hybrids in some lakes. There is a need to rule out the possibility that some populations of $D$. pulicaria are polymorphic at $L D H$ due to introgression with $D$. pulex. This possibility does not seem unlikely in light of apparent introgression at other loci and the pulicaria-like head shape of individuals that were assigned to $D$. pulex on the basis of their $L D H$ phenotype. However, in the absence of such information, the present study follows past practice in defining membership in $D$. pulicaria on the basis of homozygosity for the $F$ allele at $L D H$. It is important to emphasize that the exclusion of information on any polymorphic locus will not bias final conclusions concerning the breeding system employed by the population under study.

An earlier study (Hebert et al., 1993) involving the genetic analysis of more than 500 populations of the $D$. pulex complex from ponds showed that $D$. pulex was broadly distributed across Canada, while $D$. pulicaria was present only in the west. In the west, D. pulicaria was ordinarily dominant in ponds with the largest surface areas. The present study confirms that $D$. pulicaria is the dominant taxon in lakes across much of the continent, a result which might have been anticipated on the basis of prior morphological studies (Brooks, 1957; Brandlová et al., 1972; Hrbáček, 1987).

Populations of $D$. pulicaria in lakes show marked local variation in gene frequency, comparable in extent to that detected in other populations of pond zooplankton (Hebert, 1987; Boileau et al., 1992). In common with these earlier studies, the extent of divergence is only modestly increased as the geographic scope of investigation is extended. Certainly, lake populations of $D$. pulicaria show little geographic patterning in gene frequencies across North America. Genetic distance analysis does suggest, however, that pond populations of $D$. pulicaria show genetic divergence from lake populations. In part, this divergence 
appears to reflect the greater exposure of pond D. pulicaria to introgression from $D$. pulex. For instance, the $S$ allele at $F U M$, which occurs at a frequency of 38 per cent in western populations of $D$. pulex, occurs at a frequency of 3 per cent in pond $D$. pulicaria, but was never detected in lake $D$. pulicaria. Similarly the $F$ allele at GOT, which has a frequency of 35 per cent in D. pulex, was more than twice as common in pond than lake D. pulicaria ( 5 per cent versus 2 per cent).

There is some experimental evidence that supports the possibility of introgression between these taxa. Innes and Hebert (1988) experimentally produced hybrids between $D$. pulex and $D$. pulicaria, while Larsson (1991) carried out a backcross between a natural $F_{1}$ hybrid and $D$. pulex. In the second experiment the backcross offspring were not only viable, but also apparently able to reproduce sexually. Both the gene frequency data from natural population surveys and these experimental studies suggest that introgression is likely between these two species. However, their morphological differences and marked genetic divergence support their continued taxonomic recognition.

Prior work (Hebert et al., 1993) has established that populations of $D$. pulicaria from pond habitats in western Canada employ two modes of reproduction cyclic parthenogenesis and obligate parthenogenesis. Most populations from the prairie provinces are obligate asexuals, while cyclic parthenogens are dominant in British Columbia. This study suggests that lake populations of $D$. pulicaria show the same breeding system diversity. There is a need to verify the occurrence of obligately asexual populations in lakes, as it can be argued that apparent examples simply represent cyclically parthenogenetic populations exposed to little recruitment from sexual eggs. This explanation is perhaps made less likely by the detection in this study of a geographical pattern suggesting the greater abundance of obligate asexuals in the western than central group of populations. However, this hypothesis can only be definitively tested through breeding studies on isofemale lines obtained from lakes dominated by asexual lineages.

While the occurrence of obligate asexuality requires validation, the conclusion that most lake populations of D. pulicaria reproduce by cyclic parthenogenesis is robust. It is very unlikely that genotypic distributions will, by chance, approximate those expected in a sexual population. This observation further suggests that populations of $D$. pulicaria are exposed to a substantial amount of sexual recruitment. When coupled with the results of an earlier study (Hebert et al., 1993) the present analysis suggests a divergence in breeding system linked to habitat, with pond populations of $D$. pulicaria dominated by obligate asexuals and lakes by cyclic parthenogens. Efforts to verify this dichotomy should focus on sites in central Canada, where large numbers of lake populations of $D$. pulicaria occur in proximity to pond populations already known to be dominated by obligate asexuals.

Cyclic parthenogenesis is clearly the ancestral breeding system in the genus Daphnia and few species have made the transition to obligate asexuality. It is intriguing that D. pulex, D. pulicaria and a third closely related taxon ( $D$. middendorffiana) are the only species in the subgenus Daphnia known to reproduce in this fashion (Hebert \& McWalter, 1983; Weider et al., 1987; Hebert et al., 1988; Lynch et al., 1989). Innes and Hebert (1988) have attributed the adoption of asexuality to a sex-linked meiosis suppressor that permits the 'contagious' spread of asexuality via interbreeding. The growing evidence of introgression between these species supports the conclusion that the breeding system transitions in all three species owe their origin to the diffusion of a single mutation across species boundaries.

The parameters determining breeding system distributions are less clear. It is now known that obligately asexual lineages of the $D$. pulex complex are not restricted to North America. There is evidence that populations from mesic sites in Europe largely reproduce by cyclic parthenogenesis (Ruvinsky \& Lobkov, 1981; Ward \& Geissler, 1988; Hebert et al., $1989 \mathrm{~b}$ ), while those from montane and tundra habitats (Černý, unpub. obs.; Hobaek et al., in press; Ward et al., in prep.) are obligate parthenogens. Detailed studies in North America have shown broad geographical patterning in breeding system shifts. Populations of $D$. pulex show, for example, a shift from obligate to cyclic parthenogenesis which is closely coincident with the prairie-forest ecotone (Hebert et al., 1993). The present study hints at a new level of complexity, suggesting that neighbouring sympatric populations of $D$. pulicaria show differing breeding systems with pond populations dominated by obligate asexuals and lakes by cyclic asexuals. It is becoming increasingly clear that breeding system variation in the $D$. pulex complex is both dynamically and structurally complex. The exploration of such complexity seems likely to contribute to our understanding of the evolutionary fate of asexuals.

\section{Acknowledgements}

This research programme was supported by an operating grant from the Natural Sciences and Engineering Research Council of Canada to P.D.N.H. We thank P. Gajda for field assistance and D. J. Taylor and M. Boileau for comments on this manuscript. 


\section{References}

BOILEAU, M. G., HEBERT, P. D. N. AND SCHWARTZ, S. S. 1992. Nonequilibrium gene frequency divergence: persistent founder effects in natural populations. J. Evol. Biol., 5, 25-39.

BRANDLOVA, J., BRANDL, Z. AND FERNANDO, C. H. 1972. The Cladocera of Ontario with remarks on some species and distribution. Can. J. Zool., 50, 1373-1403.

BROoKs, J. L. 1957. The systematics of North American Daphnia. Mem. Conn. Acad. Arts Sci., 13, 1-180.

HEBERT, P. D. N. 1978. The population biology of Daphnia (Crustacea, Daphniidae). Biol. Rev., 53, 387-426.

HEBERT, P. D. N. 1987. Genotypic characteristics of cyclic parthenogens and their obligately asexual derivatives. In: Stearns S. C. (ed.), Evolution of Sex and its Consequences, Birkhauser Verlag, Basel, pp. 175-195.

HEBERT, P. D. N. AND BEATON, M. J. 1989. Methodologies for Allozyme Analysis using Cellulose Acetate Electrophoresis. Helena Laboratories, Beaumont, Texas.

HEBERT, P. D. N. AND McWALTER, D. B. 1983. Cuticular pigmentation in arctic Daphnia: adaptive diversification of asexual lineages? Am. Nat., 122, 286-291.

HEBERT, P. D. N., WARD, R. D. AND WEIDER, L. J. 1988. Clonaldiversity patterns and breeding-system variation in Daphnia pulex, an asexual-sexual complex. Evolution, 42, 147-159.

HEBERT, P. D. N., BEATON, M. J., SCHWARTZ, S. S. AND STANTON, D. J. 1989a. Polyphyletic origins of asexuality in Daphnia pulex. I. Breeding-system variation and levels of clonal diversity. Evolution, 43, 1004-1015.

HEBERT, P. D. N., SCHWARTZ, S. S. AND HRBÁCEK, J. 1989b. Patterns of genotypic diversity in Czechoslovakian Daphnia. Heredity, 62, 207-216.

HEBERT, P. D. N., SCHWARTZ, S. S., WARD, R. D. AND FINSTON, T. L. 1993. Macrogeographic patterns of breeding system diversity in the Daphnia pulex group. I. Breeding systems of Canadian populations. Heredity, 70, 148-161.

HOBAEK, A., WEIDER, L. J. AND WOLF, H. G. 1993. Ecological genetics of Norwegian Daphnia III. Clonal richness in an arctic apomictic complex. Heredity, 71, 323-330.

HRBACEK, J. 1957. Uber die angebliche Variabilität von Daphnia pulex. L. Zool. Anz., 162, 116-126.

HRBÁCEK, J. 1987. Systematics and biogeography of Daphnia species in the northern temperate region. In: de Bernardi,
R. and Peters, R. H. (eds), Daphnia. Mem. Ist. Ital. Idrobiol., 45, 37-76.

INNES, D. J. AND HEBERT, P. D. N. 1988. The origin and genetic basis of obligate parthenogenesis in Daphnia pulex. Evolution, 42, 1024-1035.

JACOBS, J. 1990. Microevolution in predominantly clonal populations of pelagic Daphnia (Crustacea: Phyllopoda): Selection, exchange and sex. J. Evol. Biol., 3, 257-282.

LARSSON, P. 1991. Intraspecific variability in response to stimuli for male and ephippia formation in Daphnia pulex. Hydrobiologia, 225, 281-290.

LYNCH, M., SPITZE, K. AND CREASE, T. 1989. The distribution of life-history variation in the Daphnia pulex complex. Evolution, 43, 1724-1736.

MORT, M. A. AND Wolf, H. G. 1985. Enzyme variability in largelake Daphnia. Heredity, 55, 27-36.

MORT, M. A. AND wolf, H. G. 1986. The genetic structure of large-lake Daphnia populations. Evolution, 40, 756-766.

NEI, M. 1978. Estimation of average heterozygosity and genetic distance from a small number of individuals. Genetics, 89, 583-590.

RUVINSKY, A. O. AND LOBKOV, Y. 1981. Esterase genes in Daphnia pulex: linked inheritance and genotypic distribution in natural populations. Theor. Appl. Genet., 60, 113-117.

SWOFFORD, D. L. AND SELANDER, R. B. 1989. BIOSYS-1: A computer program for the analysis of allelic variation in population genetics and biochemical systematics, Illinois Natural History Survey.

WARD, R. D. AND GEISSLER, P. A. 1988. Reproductive mode in populations of Daphnia pulex and Daphnia obtusa from the East Midlands of Britain. Freshwat. Biol., 20, 69-73.

WEIDER, J. W., BEATON, M. J. AND HEBERT, P. D. N. 1987. Clonal diversity in high-arctic populations of Daphnia pulex, a polyploid apomictic complex. Evolution, 41, 1335-1346.

WEIDER, L. J. AND HEBERT, P. D. N. 1987. Ecological and physiological differentiation among low-arctic clones of Daphnia pulex. Ecology, 68, 188-198.

WORKMAN, P. L. AND NISWANDER, D. J. 1970 . Population studies on southwestern Indian tribes. II. Local genetic differentiation in the Papago. Am. J. Hum. Genet., 22, 24-49.

WRIGHT, s. 1978. Evolution and Genetics of Populations, Vol. 4: Variability within and among natural populations, University of Chicago Press, Chicago. 